Iwona MASSAKA

Uniwersytet Mikołaja Kopernika, Toruń

\title{
Radiowa manipulacja słuchaczem za pomocą materiału muzycznego
}

$\mathbf{B}_{\text {podawanych im informacji, w tym tak prostych jak prognoza pogody. }}^{\text {adania OBOP-u wykazuja, że około } 75 \% \text { słuchaczy radia nie rozumie }}$ Nie są w stanie skoncentrować się dłużej niż kilka minut na wypowiedzi dziennikarza. Radio będące przede wszystkim źródłem informacji przekazywanych w formie korespondencji, komentarzy, reportaży i dyskusji męczy i zniechęca większość słuchaczy ${ }^{1}$. Pewna, stosunkowo nieliczna grupa dziennikarzy radiowych, uznaje te fakty za niepokojące. Wskazuje ich przyczynę po stronie radia, nie zaś po stronie odbiorców. Dziennikarze ci, wiążąc swoją pracę z powinnością obywatelską i obowiązkiem etycznym otwarcie mówią, że te aspekty ich profesji zostały zaniedbane. Radio - według nich - powinno być instrumentem opiniotwórczym, źródłem rzetelnej i uporządkowanej informacji, a także miejscem debaty publicznej, źródłem rozrywki zaś - dopiero w dalszej kolejności. Niski poziom rozumienia, a - w konsekwencji - zainteresowania programami informacyjnymi i edukacyjnymi to, ich zdaniem, skutek komercjalizacji radia marginalizacji jego funkcji kulturotwórczej i rezygnacji z roli otwartego forum dyskusyjnego, z pomocą którego mogłyby upowszechniać się postawy obywatelskie - na rzecz wąsko pojętego interesu poszczególnych rozgłośni radiowych i fałszywie pojętego interesu słuchacza. Zwracają uwagę, że wychodzenie naprzeciw masowym oczekiwaniom sprowadza się do radiowego eskapizmu i pogłębiania i tak już znacznego infantylizmu słuchaczy, zainteresowanych głównie rozrywką. Poglądy te zderzają się z poglądami ogromnej rzeszy menagerów radiowych - tzw. media workers, różniących się od dziennikarzy rozumieniem roli, jaką w kraju liberalno-demokratycznym powinno odgrywać radio. Owi funkcjonariusze

1 Zob.: J. Beliczyński, Model radia informacyjnego, „Radio Lider” 2003, nr 8, s. 34; Z. Gieniewski, O stanie radiowej informacji i konieczności jego poprawy, „Radio Lider" 1998, nr 2, s. 10. 
radiowi na równi z dziennikarzami krytykującymi fetyszyzację marketingu i reklamy w radiu, śledzą wyniki badań OBOP-u, jednak nie po to, by zastanawiać się nad kondycją obywatelską Polaków w związku z zadaniami, jakie podejmuje dziś radio, lecz po to, by dowiedzieć się jakich programów radiowych większość z nich lubi słuchać. Słuchacz traktowany jest przez nich wyłącznie jako konsument, którego gusty i potrzeby pracownicy radia muszą uwzględniać. Programy radiowe są towarem, który musi znaleźć nabywcę, poddaje się je testowi rynku by sprawdzić czy ich emitowanie będzie opłacalne. Pozyskiwanie słuchacza, które jest warunkiem istnienia i prosperowania prywatnych zwłaszcza rozgłośni radiowych, staje się jedynym, realnie podejmowanym przez nie zadaniem. Oczywiście, żaden z redaktorów naczelnych zarówno rozgłośni publicznych, jak i niepublicznych ${ }^{2}$ oficjalnie nie sprowadza ich działalności do handlu i usług. Wręcz przeciwnie: na łamach periodyków fachowych, wśród priorytetowych funkcji radia wymienia się funkcję informacyjna, edukacyjną i opiniotwórczą. Pisze się, że słuchanie radia poszerza horyzonty myślowe, dostarcza narzędzi intelektualnych podnoszących zdolność samodzielnej argumentacji, tłumaczy zachodzące w świecie zmiany. Radio jakoby przyczynia się do upowszechniania wzorców poprawnej polszczyzny i stwarza możliwość uczestniczenia w wolnej dyskusji na tematy interesujące słuchaczy. Przypisuje się także radiu skuteczność w sprawowaniu kontroli wobec działań organów władzy państwowej ${ }^{3}$. Współczesne widzenie roli radia jest jak najbardziej zgodne z założeniami pierwszych twórców radia w Polsce, wizja ta nie znajduje jednak odzwierciedlenia w kształcie programów radiowych. Wyjątkiem pod tym względem może być jedynie program I i II PR, które - w jednolitej pod względem treści i formy - komercyjnej produkcji radiowej korzystnie się wyróżniają.

2 W dobie wszechogarniającej komercjalizacji, podział na radio publiczne i komercyjne przestaje mieć uzasadnienie. Po włączeniu radia trudno zorientować się, której stacji radiowej słuchamy, o ile nie jest to audycja nadawana przez jedna $\mathrm{z}$ nielicznych stacji o specyficznej formule programowej i małej słuchalności jak np. Jazz Radio czy Radio Classic. Zarówno rozgłośnie publiczne, jak i niepubliczne koncentrują wysiłki na pozyskaniu jak największej liczby słuchaczy, a popularność programów radiowych przekładana jest głównie na możliwość zarobku. Zdecydowana ich większość redagowana jest z myślą o zapotrzebowaniu i możliwościach percepcji słuchacza masowego. Podział na radio publiczne i komercyjne można zastąpić podziałem na radio masowe $\mathrm{i}$ niszowe.

${ }^{3}$ Zob.: J. Beliczyński, Model radia informacyjnego ..., s. 34. 
Polskie Radio w latach 1925-1935 było elitarnym medium nastawionym na wybraną publiczność, której krąg szybko poszerzał się - radio integrowało społeczeństwo wokół znaczących celów państwowych. Po przegranej kampanii wrześniowej 1939 roku przeszło ono do podziemia. Działało głównie jako serwis informacyjny dla aliantów, stając się częścią Polskiego Państwa Podziemnego, które m.in. planowało rozwój radiofonii w odrodzonym państwie polskim. W tych pierwszych planach koncentrowano się na kulturotwórczej i informacyjnej roli radia, funkcję relaksacyjną traktując jako marginalną. Po wojnie radio stało się narzędziem indoktrynacji komunistycznej i pozostało nim do połowy lat 70-tych, kiedy to rola społeczna radia zmalała pod wpływem rozwijającej się telewizji - podstawowego narzędzia propagandy epoki Edwarda Gierka. W końcowej fazie lat 80-tych popularność radia wzrosła. Prorządowa, całkowicie objęta cenzurą telewizja nudziła i irytowała społeczeństwo, które coraz wyraźniej sygnalizowało potrzebę wolności słowa w mediach. Radio znacznie szybciej niż telewizja na potrzebę tę zareagowało, zrazu tylko audycjami rozrywkowymi o treści kontestatorskiej (najwięcej emitował ich program III PR), nieco później powstała rozgłośnia podziemna Radia Solidarność, która przyjęła model radia informacyjnego ${ }^{4}$. Rozrywka w radiu bardzo często wówczas przybierała postać satyry politycznej. W połączeniu z piosenkami o wymowie antykomunistycznej urosła do roli kreatora nowej świadomości społecznej. Nigdy wcześniej ani nigdy później nie była ona tak wyraźnie sprzężona z edukacją. U początków lat 90-tych edukacyjna rola radia nie była jedynie deklaracją, tym bardziej, że dziennikarze radiowi zabiegali nie tylko o obfitość, lecz także o rzetelność informacji i czytelność komunikatów.

Kontekst polityczno-kulturowy, który sprzyjał rozwojowi radia prawdziwie informacyjnego i kulturotwórczego już nie istnieje. Radio przestało być w opozycji do systemu. Dawniej coś demaskowało, zwalczało. Dziś usadowiło się przy władzy, już nie kontestuje, nie kwestionuje zasad jej działania. Stopniowo zrezygnowało z funkcji uczestnictwa w debacie publicznej. Toporna, biurokratyczną, policyjną cenzurę polityczną zastapiła cenzura rynku. Informacje w systemie komunistycznym były selekcjonowane według kryterium politycznego, dziś selekcjonowane są pod kątem potrzeb masowej publiczności i zainteresowanych sukcesem

4 Por.: J. Mikułowski Pomorski, Audio contra video. Ku czemu daży radio?, w: Radio. Szanse $i$ wyzwania. Materiaty konferencji Kulturotwórcza rola radia, red. T. Leśniak, Kraków 1997, s. 9. 
finansowym ${ }^{5}$. Niby mamy takie radio, jakie zachwyciło Pawlaka - bohatera popularnej trylogii filmowej Sylwestra Chęcińskiego (w filmie jest scena, gdzie zaproszony do lokalnej amerykańskiej rozgłośni radiowej Pawlak mówi do Kargula: „U nas radia tylko słucha się, a tu można mówić!'). Dziś w Polsce każdy może powiedzieć kilka słów na antenie, o ile uda mu się połączyć telefonicznie z rozgłośnią radiową. Nie ma to jednak nic wspólnego z uczestnictwem w debacie publicznej. Radio nie jest dziś sceną debaty co najmniej $\mathrm{z}$ dwóch powodów.

1. Czas antenowy od dawna nie jest już czasem przeznaczonym na opiniotwórczą refleksję. Stał się inwestycją, która ma przynieść zysk rozgłośni, a niekoniecznie słuchaczom. Prestiż radia mierzony jest w kategoriach ilości (słuchaczy, informacji, dostarczanej rozrywki, ofert od sprzedawców reklam i pieniędzy ze sprzedaży reklam), nie zaś w kategoriach jakości. Drugim - obok ilości - filarem, na którym wznosi się merkantylnie rozumiany sukces radia - jest rozmaitość. Jest to wprawdzie jedynie rozmaitość form wypowiedzi, nie zaś rozmaitość tematów, idei, opinii, a w sferze muzycznej - różnych rodzajów muzyki, lecz i tego rodzaju pluralizm znajduje uznanie, szczególnie w krajach ekskomunistycznych, gdzie ludzie mająjeszcze w pamięci płynącą z odbiorników radiowych przez kilkadziesiąt lat jednolita, oddaloną od realiów życia stylistykę. Ogromny odsetek słuchaczy zresztą nie zauważa, że rozmaitość formalna - mnogość używanych na antenie form dźwiękowych i językowych, od języka literackiego do żargonu, a także dynamika i ekspresja wypowiedzi - są tylko substytutem pluralizmu w sferze treści. W krajach, gdzie transformacja systemu w kierunku demokracji liberalnej postępuje opornie, gdzie zadeklarowane zasady demokratyczne z różnych przyczyn znajdują w praktyce albo ograniczone albo symulacyjne zastosowania, tam język mediów urozmaicany jest w celach kompensacyjnych - chodzi o to, by odwrócić uwagę społeczeństwa od istoty problemu, którym jest przepaść pomiędzy deklaracją a realizacją różnych zasad.

Pracownicy radia koncentrują się na tym, by w jak najkrótszym czasie pozyskać jak największą ilość słuchaczy. Prawie wszystkie programy radiowe kierowane są zatem do odbiorcy masowego. Abstrahując od zasadności takiego wyboru - czy są one rzeczywiście dostosowane do potrzeb i oczekiwań tego rodzaju odbiorcy? Tak - biorąc pod uwagę treść i nie biorąc pod uwagę formę przekazu treści. W programach tworzonych

${ }^{5}$ Zob.: R. Kapuściński, Lapidarium IV, Warszawa 2000, s. 20, 83. 
z myślą o słuchaczu masowym zazwyczaj nie wykracza się poza problematykę z kręgu pop-kultury i tego fragmentu rzeczywistości, który większość ludzi zna i rozumie. Sprawy publiczne i sytuacje polityczne, wymagające zrozumienia czegoś więcej, niż „kto - kogo” - przedstawia się w sposób uproszczony, najczęściej sensacyjny. Dba się o to, by odbiorcy nie nudzić i nie zmuszać do wysiłku. $Z$ drugiej jednak strony słuchanie najbardziej nawet masowego radia - wbrew założeniom jego twórców i oczekiwaniom odbiorców - wymaga koncentracji. Słuchacza zalewa potok zmasowanych danych i szybko zmieniających się skompilowanych melodii, nagranych na kilku ścieżkach dźwiękowych, odtwarzanych w tym samym czasie. Każda wyemitowana minuta programu radiowego ma być opłacalna ${ }^{6}$, więc czyni się starania, by w jak najkrótszym czasie zawrzeć jak najwięcej słów i materiału muzycznego. Przeciętny słuchacz, który - zgodnie z ustaleniami OBOP-u - nie jest w stanie skupić uwagi na komunikacie werbalnym dłużej niż kilka minut, z nie mniejszym trudem odbiera komunikat trwający co prawda nie dłużej niż minutę, ale za to nadawany w nienaturalnie szybkim tempie i z muzyką w tle. Szybkie tempo przekazu powoduje u odbiorcy chaos poznawczy i zmęczenie. Wartość edukacyjna komunikatów zbliżona jest do zera. W latach 40-tych przyjmowało się, że podczas 1 minuty czasu antenowego można, z pożytkiem dla słuchacza, wypowiedzieć najwyżej 120-130 wyrazów. Dziś, w Programie III PR słyszymy 104-224 słów w ciągu minuty, w Radiu Zet - od 227-230 słów w ciągu minuty. Rekordy w szybkim mówieniu biją pracownicy stacji RMF-FM wypowiadając 300-400 słów w ciągu minuty ${ }^{7}$.

Wymagane tempo wypowiedzi $\mathrm{w}$ połączeniu $\mathrm{z}$ ograniczeniem czasu wypowiedzi do kilku minut wyklucza jakąkolwiek debatę w studio. Nawet gdyby poczyniono wysiłki zaaranżowania jej, byłaby mało zrozumiała i bezpłodna. Debaty publiczne prowadzone w innych miejscach i transmitowane, poddawane są takiej redukcji, że nie przypominają już debat, lecz zbiór opinii, które trudno powiązać wspólnym kontekstem. $\mathrm{Z}$ punktu widzenia interesu radia masowego transmisja debat publicznych jest działaniem na szkodę firmy - audytorium masowe nie zgłasza zapotrzebowania na wysłuchiwanie tego rodzaju nagrań.

6 Skuteczność, utożsamiana często z opłacalnością radia komercyjnego polega na tym, że po zbadaniu rynku - czyli zorientowaniu się jakie grupy społeczne słuchają radia o danej porze dnia czy nocy - dostosowuje się treść i formę programu do gustów i zainteresowań tego odbiorcy, którego jednocześnie można „sprzedać” reklamodawcom.

7 Zob.: J. Waglewski, Stare dobre radio, ,Radio-lider” 1999, nr 6, s. 8-9. 
2. Jeśli słuchacz masowy nie chce słuchać debat na antenie radia, tym bardziej nie jest zainteresowany uczestnictwem w nich. Dziennikarze radiowi rezygnują $\mathrm{z}$ inicjowania i rejestrowania debat $\mathrm{w}$ obawie, że nadając taki materiał obniżą atrakcyjność programu, nie wywołując przy tym żadnego oddźwięku społecznego. Reportaże, dyskusje, obszerniejsze komentarze do wydarzeń politycznych, wywiady z politykami i innymi osobami publicznymi nadawane są we wczesnych godzinach rannych, późnych porach wieczornych lub w nocy, kiedy czas antenowy jest najtańszy. Możliwości nagrania rozmów przeznaczonych do emisji w radiu masowym z udziałem kompetentnych osób publicznych ogranicza konwencja, w jakiej prezentowane są na antenie. Zaproszonemu gościowi przerywa się wypowiedź, by wyemitować spot reklamowy, dyskusjom o polityce towarzyszy muzyka z listy przebojów, co daje efekt karykaturalny ${ }^{8}$. Dla potencjalnych dyskutantów, których wypowiedzi mogłyby przyczynić się do podniesienia poziomu intelektu i świadomości odbiorcy, są to okoliczności najczęściej skłaniające do odrzucenia propozycji nagrania.

$\mathrm{W}$ okresie przed- i powojennym, działalność radia wiązano z misją społeczna, a dziennikarstwo z powołaniem. Kulturotwórcza i informacyjna rola radia była sprawą doniosła, podejmowaną w licznych publikacjach $^{9}$. Dziś pracownicy radia i teoretycy dziennikarstwa radiowego również wspominają o misyjności radia ${ }^{10}$ oraz upowszechnianiu przez nie kultury i wiedzy, ale wielu z nich najwyraźniej inaczej niż pierwsi twórcy radia te sprawy rozumie. Mamy tu do czynienia z przedefiniowaniem pojęcia misji, wolności w mediach, informacji, wiedzy, kultury, edukacji, a także profesji dziennikarskiej.

Jeżeli - przy określeniu zadań, jakie powinno podejmować radio w kraju liberalno-demokratycznym - pozostaniemy przy słowie „misja”, to powinno nią być przede wszystkim dostarczanie prawdziwych, wieloaspektowych komunikatów na temat zjawisk i sytuacji w kraju i za granicą. Nadawane systematycznie i zrozumiale, przeradzają się po pewnym czasie w wiedzę, w jakiś mniej lub bardziej spójny obraz rzeczywistości. Misją radia powinno być także pobudzanie aktywności obywatelskiej, co jest realne tylko w stosunku do świadomego odbiorcy.

8 Por. np. audycję pt. Puls Trójki.

9 Zob.: J. Tuszewski, Rytm, ,przestrzeń ” i ruch czyli reguly Zenona Kosidowskiego, „Zeszyty Prasoznawcze” 1989, nr 3, s. 38.

${ }_{10}$ Zob. np.: B. N. Łopieńska, M. Król, Wywiad z Andrzeyem Woyciechowskim, „Res Publica Nowa” 1994, nr 3, s. 43. 
Co mają na myśli dziennikarze radiowi, gdy mówią dziś o misji radia? Jeden z dziennikarzy masowego radia niepublicznego wyjaśnił, że dla niego misją jest „pokazywanie pozytywów”, „nie narzekanie” i zapoznawanie słuchacza $\mathrm{z}$ aktualnymi listami przebojów. Znajomość modnych szlagierów została w tej wypowiedzi utożsamiona z „wiedzą o świecie" ${ }^{\text {"1 }}$. Zatem misją dziennikarza radiowego można dziś nazwać np. propagandę optymizmu i swoiście pojętą edukację. Inni dziennikarze również misyjność radia rozumieją jako szerzenie wiedzy, w rzeczywistości mając na myśli zalew słuchacza informacjami. Mylą pojęcie wiedzy z pojęciem zbioru wiadomości. Tak czy owak - zgodnie z najlepszymi tradycjami dziennikarstwa - wielu pracowników radia misyjność zdecydowanie kojarzy z informowaniem słuchacza. O ile jednak pionierzy sztuki radiowej informację bez komentarza odkrywającego powiązania pomiędzy wymienianymi faktami i pozwalającego wyprowadzić z nich dalsze konsekwencje uważali za mało użyteczną, bardziej skupiając wysiłki na komunikowaniu, rzeczywiście pomocnym w pokonywaniu kolejnych szczebli drabiny światopoglądowej, o tyle dziś informacja podawana bez racjonalnego klucza jest produktem rynkowym - jej rozpowszechnianie jest dobrym interesem, a elementem w procesie edukacji tylko przy okazji i nie zawsze. Komentarz do informacji stał się luksusowym dodatkiem, bo zabiera czas antenowy, na ogół nudząc odbiorcę, który nie oczekuje wyjaśnień genetycznych opisywanych zjawisk, lecz chce wiedzieć przede wszystkim jak dany fakt wpłynie na jego własną sytuację życiową. Potrzebuje zatem kolejnych informacji dotyczących tego odcinka świata, w którym się znajduje, nie zaś wielowymiarowych analiz ${ }^{12}$. Ale przede wszystkim potrzebuje rozrywki. Radio potrzeby te podtrzymuje.

O ile satyrę i edukację udało się dziennikarzom w latach 90-tych udatnie połączyć, tak zestawienie efektów rozrywkowych z potokiem nie powiązanych ze sobą krótkich informacji jest bezwartościowe, a nawet szkodliwe. Informacja czytana w serwisie nie powinna przekraczać 40 sekund, a w wyjątkowych wypadkach półtorej minuty, więc słuchacz dowiaduje się dużo, ale nic z tego nie rozumie, ponieważ nie ma czasu by pomyśleć o tym, czego się dowiedział. Ważna stała się informacyjność,

11 Zob.: B. N. Łopieńska, M. Król, Wywiad z Andrzeyem Woyciechowskim, „Res Publica Nowa" 1994, nr 3, s. 43.

12 I. Trzciniecka-Schneider, Postawy współczesnego polskiego odbiorcy wobec mediów. Pewne historyczne i filozoficzne uwarunkowania, „Zeszyty Prasoznawcze” 1995, nr 3-4, s. 75. 
a nie racjonalność, zamiast przedstawiać ciag faktów, oznajmia się je bez związku przyczynowo-skutkowego. Informacje podawane są bez kontekstu wprowadzającego i w przypadkowej kolejności, bez uporządkowania ich według hierarchii ważności. Postulat bawienia słuchacza za wszelką cenę narzuca konwencję show, w której można mówić dosłownie o wszystkim: o wojnie, o zbrodniach, o klęskach żywiołowych, sensacjach ze świata artystycznego, modach żywieniowych, planach ekonomicznych itd. W ten sposób kształtuje się słuchacza obojętnego na wszystko, bezmyślnego, bezkrytycznego, podatnego na manipulację. Wiele spraw i problemów, które mogłyby budzić niepokój lub lęk są spychane na margines, usuwane z pola widzenia. Można także zaobserwować tendencję do odwracania uwagi odbiorcy od istoty problemu ku elementom drugorzędnym.

Radio buduje dramaturgię bez finału, co utrudnia zrozumienie tego, czego w założeniu słuchacz miał się dowiedzieć. Informacje, które dotyczą wydarzenia rozciagniętego w czasie jak wojna, działalność antyterrorystyczna czy katastrofa ekologiczna powinny zawierać przypomnienie tych, które ją poprzedzały. Tymczasem rzadko towarzyszy im kontekst wyjaśniający przyczyny zaistniałych faktów, jak również nie wraca się do spraw, które w odczuciu dziennikarzy uległy przedawnieniu. Jednego dnia dowiadujemy się o ważnej sprawie, a po kilku dniach nie ma już najmniejszej wzmianki o tym jak sprawa ta się potoczyła, znika na zawsze ${ }^{13}$.

W zderzeniu z nadmiarem informacji, u ludzi nie przyzwyczajonych do wysiłku intelektualnego włącza się psychologiczny mechanizm obronny - przestają oni przyjmować kolejne komunikaty z obawy przed koniecznością zmiany raz wyrobionych poglądów. Przestają myśleć po tym, gdy z trudem, po wysłuchaniu wielu niespójnych informacji, uda im się wyrobić jakiś pogląd - nie chcą go utracić i popaść w konieczność rewidowania go. Dziś, kiedy wartość informacji mierzy się jej atrakcyjnością, a kryterium prawdy i kłamstwa utraciło priorytet, poglądy polityczne, społeczne czy pokoleniowe stały się jakby mniej ważne niż wyobraźnia, umiejętność zaskakiwania i niespecjalnie wyrafinowane poczucie humoru. W dziennikarstwie pierwszoplanowy staje się problem formy przekazu treści, a nie samej treści. Nawet tradycyjnie pojęta niezależność radia praktycznie już nie istnieje. Media sprzężone są z gospodarką i kapitałem, a z punktu widzenia kapitału informacją rządzą takie same prawa jak reklamą. Prawda ma się przede wszystkim sprzedawać, czyli musi być

13 R. Kapuściński, Lapidarium IV ..., s. 96. 
atrakcyjna. Informacje ważne i prawdziwe, ale nie posiadające żadnej atrakcyjności - ani nie zaskakujące, ani nie sensacyjne, ani nie zabawne - nie kwalifikują się do serwisu.

Radio pretenduje dziś do roli jednego z głównych dostarczycieli rozrywki. Prezenterzy radiowi prowadzą dyskusje w stylu niezawisłego luzu. Slogany reklamowe, wypowiedzi osób prowadzących audycje radiowe, serwisy informacyjne, piosenki, sygnały dźwiękowe czynią z programów radiowych coś w rodzaju musicalu. Materiał muzyczny wybitnie przyczynia się do tworzenia programowej atmosfery beztroski i optymizmu. Istotą radia jest dziś muzyka popularna, w tym uproszczona muzyka etniczna. Radio zwokalizowało komunikat i zafałszowało jego sens. Nawet mówiąc o wojnie lub kataklizmie prezenterzy są tak radośni jakby opowiadali dowcip. Komunikaty poprzedzane są sygnałem muzycznym na początku, kilka razy w trakcie jego emisji, na końcu, a niekiedy również w tle. Ornamentyka muzyczna jest wszechobecna, śpiewa się komunikaty o pogodzie, meldunki o sytuacji na drodze, zapowiedzi audycji, numery telefonów. Niektóre sygnały dźwiękowe są tak rozbudowane, że można przypuszczać, iż prezentowany jest jakiś nowy utwór muzyczny. Oprócz nich dużo czasu antenowego konsumuje emisja list przebojów. Materiał muzyczny jest zresztą szatkowany nie mniej niż informacje i komunikaty, słuchacz najczęściej jest skazany na wysłuchanie fragmentu wypowiedzi lub utworu muzycznego. O ile w serwisach informacyjnych nie odczytuje się w całości nawet najważniejszych oświadczeń polityków, są one przeredagowywane lub zastępowane omówieniami, o tyle muzykę prezentuje się w stylu dyskotekowym. Nagraniom nie pozwala się wybrzmieć, bo gdy tylko zbliża się koniec utworu zostaje nałożony na niego początek innego. Odtwarza się także kompilacje różnych utworów, po kilka taktów każdego, co przypomina video-clip, tyle że dźwiękowy.

Właściwą sobie formę edukacji prowadzą rozgłośnie diecezjalne i katolickie - Radio Maryja i Radio Plus. Mają one własną ofertę muzyczną: Radio Plus - szeroką, z przewagą muzyki rockowej, jako iż swoje programy kieruje głównie do młodzieży o niekoniecznie skrystalizowanym światopoglądzie religijnym, Radio Maryja - znacznie węższą, utrzymaną w tradycyjnej konwencji - w programach tej rozgłośni widoczna jest intencja ugruntowywania przekonań w pełni już przekonanych do wartości chrześcijańskich i dogmatów kościelnych słuchaczy. W obu przypadkach funkcję edukowania wolnej, świadomej i aktywnej w sferze politycznej jednostki zastapiło wychowywanie jednostki biernej, podporządkowanej normom określonym doktryną kościoła katolickiego. 


\section{Summary}

The analysis of the material broadcast by radio stations leads the Author to conclude that at present radio aspires to become one of the main providers of entertainment. The advertising slogans, statements of radio anchorpersons, news, songs or jingles make radio broadcasts something like a musical. This musical content remarkably contributes to the atmosphere of lightheartedness and optimism. Music is fragmented to the same degree as the news or announcements, and the listener is usually forced to listen to only a fragment of a speech or song. The recordings are not run to the very last sounds as when one approaches its ending the beginning of another one overlaps it immediately. Mixes of different songs are also played, including several bars of each, which is reminiscent of a video-clip for the ears. 